\title{
UPAYA MENINGKATKAN PENGETAHUAN CYBERBULLYING DI KALANGAN REMAJA MILENIAL DI SMAN 1 PLERET
}

\author{
Shulbi Muthi Sabila Salayan Putri \\ Prodi Ilmu Komunikasi, Fakultas Ilmu Sosial dan Politik,Universitas Widya Mataram \\ Ndalem Mangkubumen KT III/237, Yogyakarta 55132
}

\begin{abstract}
:
Cyberbullying is bullying happens in cyberspace mainly on social media. A form of cyberbullying is ridicule, threats, insults, or hacking. The phenomenon of cyberbullying and fatal consequences emerging from this action was suicidal. But cyberbullying that occur in Indonesia is still a trivial thing. Social medial cause few cases of cyberbullying increasing because of its characteristic that possible to spread information easily and fast. Socialization proper use of social media needs to be done to improve public awareness about the dangers of misuse of social media. The purpose of this service activity is to understand and apply the ethics in the use of social media as the current mainstream media among millennial teenagers, especially in the use of social media. As well as understanding the content and objectives in the ITE Law 11 of Article 27 of 2008 (Information and Electronic Transaction Law) for examples of cybercrime cases in the virtual world, especially cyberbully cases.
\end{abstract}

Keywords: Teen, Virtual World, Bullying, Cyberbullying,

Abstrak :

Cyberbullying adalah intimidasi yang terjadi di dunia maya terutama pada media sosial. Bentuk dari cyberbullying adalah ejekan, ancaman, hinaan, ataupun hacking. Fenomena cyberbullying banyak bermunculan dan akibat fatal dari tindakan ini adalah bunuh diri. Akan tetapi cyberbullying yang terdapat di Indonesia masih menjadi hal yang sepele. Media sosial mengakibatkan jumlah kasus cyberbullying meningkat karena karakteristiknya yang memungkinkan orang menyebarkan informasi dengan mudah dan cepat. Sosialisasi penggunaan media sosial yang tepat perlu dilakukan untuk meningkatkan kesadaran masyarakat mengenai bahaya penyalahgunaan media sosial. Tujuan dari kegiatan pengabdian ini adalah untuk memahami dan mengaplikasikan etika dalam penggunaan media sosial sebagai media mainstream saat ini di kalangan remaja milenial, khususnya dalam penggunaan media sosial. Serta pemahaman isi dan tujuan dalam UU ITE No.11 Pasal 27 Tahun 2008 (Undang Undang Informasi dan Transaksi Elektronik) terhadap contoh kasus cybercrime didunia maya khususnya kasus cyberbully.

Kata Kunci : Remaja, Dunia Maya, Bullying, Cyberbullying, 


\section{A. PENDAHULUAN}

Manusia sebagai mahluk sosial akan membutuhkan mahluk lain untuk berkomunikasi di dalam lingkungannya sehingga pada kehidupan modern saat ini peran media menjadi hal penting yang digunakan dalam berinteraksi antara satu orang dengan lainnya. Perkembangan zaman yang semakin canggih di berbagai aspek kehidupan telah membawa perubahan-perubahan yang begitu pesat terutama pada bidang ilmu pengetahuan dan teknologi (IPTEK). Kemajuan teknologi pada umumnya membawa pergeseran digital terhadap proses penyampaian dan penerimaan pesan disetiap media massa yang ada berdasarkan kegunaan dan kepuasan khalayak. Aktivitas yang dulu dilakukan secara offline telah bermigrasi ke ruang-ruang online. Media sosial menjadi media komunikasi paling efektif, transparasi dan efisien yang digunakan masyarakat modern di era keterbukaan informasi yang semakin berkembang dan meluas karena dianggap kuat dalam membentuk opini publik.

Pengguna internet saat ini dimanjakan dengan hadirnya beberapa media sosial yang digandrungi remaja milenial seperti Instagram, facebook, twitter, whatsapp, line, dan sebagainya. Menurut data Global Web Index, media sosial Instagram mengungguli media sosial lainnya seperti Facebook, Twitter, dan lainnya. Dengan ini maka pengguna Instagram di Indonesia sudah bertumbuh sebesar $215 \%$ pada tahun 2014 (Reza, 2015). Adanya media sosial di kalangan remaja membuat mereka dapat berhungan dengan teman-teman lamanya. Namun dengan munculnya media sosial di kalangan remaja juga membawa dampak negatif. Salah satu dampak negatifnya adalah bullying. Bullying dalam bahasa Indonesia berarti mengintimidasi atau mengganggu orang yang lemah baik, secara individu ataupun secara berkelompok.

Menurut Kim (2006) dalam Adilla (2009:57) bullying dapat dilakukan secara verbal, psikologis dan fisik. Sebagian besar dari kita hanya menggetahui bullying yang dilakukan secara langung atau bertemu langsung dengan target (sebutan untuk seorang korban) bullying menggunakan kontak fisilk maupun verbal. Namun sekarang ini, bullying tidak hanya terjadi dikehidupan nyata saja, bullying sekarang juga terjadi di dunia internet(cyber). Bullying yang terjadi di internet atau cyber dijuluki dengan cyberbullying. Cyberbullying sama dengan bullying yang terjadi pada umumnya, yaitu sama-sama mengintimidasi ataupun mengganggu orang yang lemah, cyberbullying ini pada umumnya banyak terjadi dimedia sosial.

Perbedaan antara Cyberbullying dengan bullying adalah tempat di mana seorang pembully atau mobbing (julukan untuk satu kelompok pem-bully) melakukan intimidasi, ancaman, pelecehan, dll terhadap target. Cyberbullying adalah kejadian ketika seorang anak atau remaja diejek, dihina, diintimidasi, atau dipermalukan oleh anak atau remaja lain melalui media internet, teknologi digital atau telepon seluler. Cyberbullying dianggap valid bila pelaku dan korban berusia di bawah 18 tahun dan secara hukum belum dianggap dewasa. Apabila salah satu pihak yang terlibat (atau keduanya) sudah berusia di atas 18 tahun, maka kasus yang terjadi akan dikategorikan sebagai cybercrime atau cyberstalking (sering juga disebut cyber harassment) (PotretOnline.Com, 12 Agustus 2013). 
Cyberbullying lebih mudah
dilakukan daripada kekerasan konvensional karena si pelaku tidak perlu berhadapan muka dengan orang lain yang menjadi targetnya. Korban yang terkena cyberbullying juga jarang yang melaporkan kepada pihak yang berwajib, sehingga banyak orang tua yang tidak mengetahui bahwa anak-anak mereka terkena bullying di dalam dunia maya. Para peneliti melakukan analisis terhadap 4.500 remaja, dan anak-anak menyatakan memiliki tingkat depresi yang lebih tinggi dari kelompok lain yang hanya dipukuli atau diejek. (inet.detik.com, 24 september 2010). Bentuk-bentuk cyberbullying yang banyak terjadi seperti mengganti foto account seseorang, menghina seseorang, dan membajak account seseorang dengan mengganti password.

Tujuan dari kegiatan pengabdian ini adalah untuk memahami dan mengaplikasikan etika dalam penggunaan media sosial sebagai media mainstream saat ini di kalangan remaja milenial, khususnya dalam penggunaan media sosial. Serta pemahaman isi dan tujuan dalam UU ITE No.11 Pasal 27 Tahun 2008 (Undang Undang Informasi dan Transaksi Elektronik) terhadap contoh kasus cybercrime didunia maya. Kebijakan yang telah dibuat tersebut diperuntukan bagi para pengguna internet agar lebih mentaati peraturan perundang-undangan yang berlaku serta menghindari dalam melakukan pelanggaran UU ITE No.11 Pasal 27 Tahun 2008 dan mencegah untuk tidak masuk keranah hukum.

\section{B. METODE PELAKSANAAN}

Peserta dalam pengabdian masyarakat ini yaitu siswa dan siswi kelas 3 SMA N 1 Pleret. Siswa dan siswi SMA N 1 Pleret, Bantul ini berjumlah 40 orang dengan usia 17 tahun keatas yang mana tergolong generasi millennial. Siswa dan siswi ini dijadikan peserta dalam pengabdian dikarenakan sangat perlu untuk mendapat perlakuan khusus dalam melihat etika pada penggunaan media sosial dikalangan remaja milenial. Metode pelaksanaan pengabdian ini menggunakan metode ceramah, simulasi,tanya jawab dan diskusi perihal etika penggunaan media sosial pada kalangan remaja milenial. Acara ini diikuti oleh 70 siswa/siswi. Kegiatan ini diawali dengan pembukaan dan kata sambutan dari masing-masing pemateri. Kemudian langsung pada acara inti yaitu penyampaian materi kepada tiap kelas siswa-siswi kelas 11 di SMAN 1 Pleret.

Penulis sendiri yang juga menjadi pembicara pertama untuk materi pertama, langsung memberikan materi mengenai cyberbullying dan etika berkomunikasi di media sosial untuk memilih pemberitaan yang dapat dipertanggungjawabkan. Di akhir sesi, banyak pertanyaan yang diajukan oleh peserta kepada pemateri. Penyampaian materi berlangsung sekitar 1 jam ditambah dengan sesi sharing dan tanya jawab antar siswa-siswi dengan pamateri. Setelah selesai, selanjutnya, acara penutup dilakukan dengan pemberian kata penutup dari masingmasing pemateri yang dilanjutkan dengan kegiatan foto bersama para siswa/siswi peserta.

\section{c. HASIL DAN PEMBAHASAN}

Tinjauan Konsep dan Hasil tentang Pengetahuan dan Pengalaman siswasiswi SMAN Pleret mengenai Cyber Bully

Tim pengabdian termasuk
penulis melaksanakan kegiatan Pengabdian Kepada Masyarakat yang berupa kegiatan diseminasi etika penggunaan media sosial terhadap cybercrime dikalangan remaja milenial. Kegiatan ini berlangsung dalam 1 hari, yaitu tanggal 22 November 2018 dari 
pukul 09.30-12.00 WIB. Pada hari dimana acara ini diselenggarakan di masing-masing kelas siswa -siswi kelas 11 SMAN 1 Pleret,Bantul.

\section{Dari hasil sharing dan tanya jawab antara siswa-siswi dengan pemateri cyberbullying, terlihat Intensitas penggunaan di dunia maya semakin lama semakin bertambah, terlihat dengan maraknya penjualan handphone atau tablet yang dijual. Selain itu, aplikasi-aplikasi yang mendukung di dalamnya semakin banyak, bervariasi dan lebih muda untuk digunakan. Hal ini yang membuat kalangan muda milenial tertarik untuk menggunakannya. Masalah cyberbullying ini muncul dikarenakan intensitas penggunaan internet yang meningkat dan munculnya media sosial, yang sering diakses para siswa.cyberbullying. Intensitas penggunaan dunia maya dalam sehari minimal bisa 6 jam, entah itu digunakan untuk browsing atau untuk membuka account media sosial yang mereka miliki. Intensitas dan motif ini merupakan kebiasaan (habitus) yang dilakukan oleh remaja dalam kehidupan sehari-hari mereka. Habitus adalah struktur untuk menghadapi kehidupan sosial.}

Menurut Bourdieu, lingkungan bukan sebagai interaksi atau ikatan lingkungan Bourdieu melihat lingkungan sebagai arena pertarungan. Lingkungan digunakan sebagai tempat untuk melindungi atau meningkatkan posisi mereka untuk mendapatkan pengakuan. Lingkungan di sekitar mereka yang menyebabkan mereka membuat account media sosial. Selain itu, siswa-siswa ini ingin meningkatkan posisi mereka juga di media sosial agar tidak dikatakan gaptek ataupun ketinggalan jaman. Selain itu, siswasiswa ini ingin meningkatkan posisi mereka juga di media sosial agar tidak dikatakan gaptek ataupun ketinggalan jaman. Lingkungan seseorang yang terkena cyberbullying juga didukung oleh keadaan lingkungan sekitarnya, baik di dunia nyata ataupun di media sosial. Jika di lingkungannya korban terbiasa untuk tetap berontak terhadap kesalahan, maka saat ia intimidasi didapatkan dimanapun, ia akan berontak dan berusaha menjaga harga dirinya. Jika sebaliknya korban merupakan orang yang simple atau orang yang tidak mau memperpanjang masalah, maka dia akan mendapatkan intimidasi yang lebih intens. Seperti yang terjadi pada sebagaian siswa-siswi tidak mau berontak terhadap cyberbullying yang diterimanya ada juga yang lebih memilih diam, sehingga ia mendapatkan ejekan dan tuduhan-tuduhan terus menerus dari temannya. dapat dilihat bahwa lingkungan juga membentuk karakter seseorang. Sebagai seorang remaja, Dibutuhkan modal untuk mempertahankan lingkungan dalam media sosial yang mereka miliki. Berdasarkan pengetahuan siswa-siswi SMAN 1 Pleret,Bantul cyberbullying adalah mengolok-olok di dunia maya dan mengambil alih account atau bisa disebut dibajak dan juga perlakuanperlakuan yang tidak sopan yang didapatkan. Terkadang, kekuatan tidak dimiliki siswa- siswi yang terkena cyberbullying lebih untuk melindungi dirinya dan siswa yang terkena cyberbullying menjadi pihak yang terintimidasi.

\section{HASIL}

Pada Penerapan PKM DI SMAN 1 Pleret ,Bantul dengan menyampaikan materi dan pengetahuan seputar cybercrime khususnya cyberbully, dapat diuraikan hasil-hasil yang dapat penulis capai antara lain:

1. Terbukanya pemahaman siswa-siswi remaja milenial di SMAN 1 Pleret,Bantul terhadap pentingnya 
literasi informasi dan pemanfaatan media sosial.

2. Siswa dan siswi SMAN 1 Pleret, Bantul sadar akan pentingnya mengetahui bahaya dan dampak-dampak penyalahgunaan media sosial.

3. Siswa-siswi SMAN 1 Pleret, memahami kekuatan dan kelemahan yang ada pada diri mereka dan menyadari untuk segera meningkatkan pengetahuan, dan implementasi / praktek keseharian mereka.

Berikut dokumentasi pada saat pelaksanaan sosialisasi etika penggunaan media sosial terhadap cybercrime pada remaja milenial di SMAN 1 Pleret.
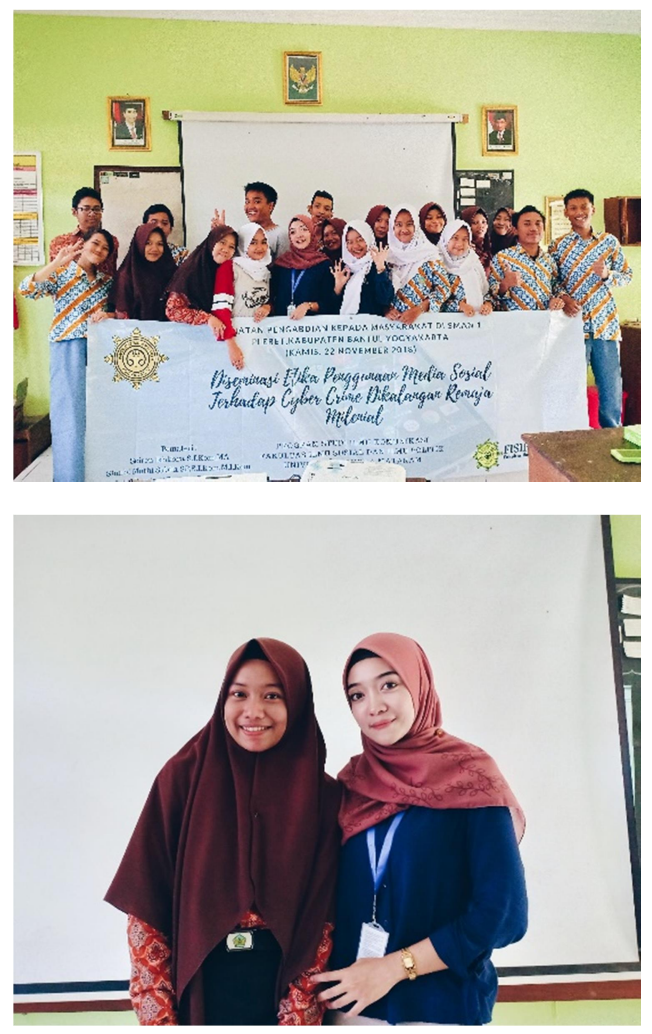

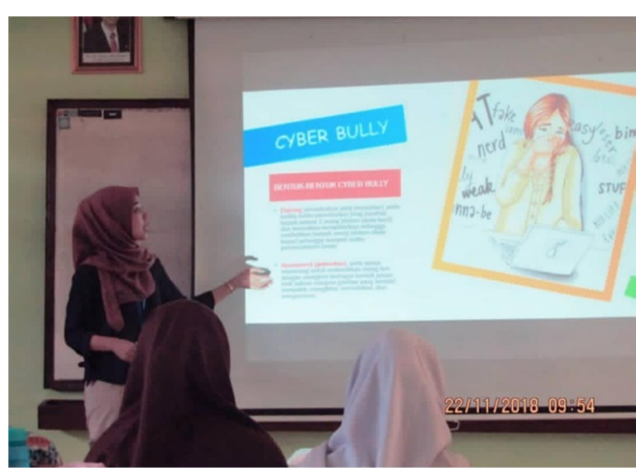

\section{D.KESIMPULAN}

Berdasarkan pelaksanaan pengabdian pada masyarakat di wilayah SMAN 1 Pleret, Bantul dapat disimpulkan sebagai berikut:

1. Kegiatan semacam ini sangat bermanfaat bagi siswa/siswi SMA Warga Surakarta, karena mereka secara tidak langsung menghadapi dan menjalaninya sehari-hari.

2. Pengaruh internet dan media sosial telah merambah di banyak daerah, termasuk di antaranya kota-kota yang jauh dari Jakarta. Hal ini tentu saja memberikan dampak positif dan negatif, terutama jika pelakunya adalah kaum anak muda. Karena itu perlunya dilakukan kegiatan sosialisasi mengenai etika berkomunikasi kepada anakanak sekolah, supaya mereka bisa mengelola akun media sosialnya dengan penuh etika.

3. Penggunaan media sosial untuk berbagai keperluan yang telah sedemikian pesat di kalangan remaja, diharapkan mampu berkontribusi positif terhadap pengembangan industri kreatif di tanah air.

4. Kegiatan ini menjadi ajang pengenalan Fakultas Ilmu Sosial dan Ilmu Politik Universitas Widya Mataram Prodi Ilmu 
Komunikasi, sehingga eksistensi dan kredibilitasnya semakin meningkat.

\section{E. DAFTAR PUSTAKA}

Abrar, Ana Nadya. 2003. Teknologi Komunikasi: Perspektif Ilmu Komunikasi.

Yogyakarta: LESFI.

Hana Machacova, dkk, Effectiviness of Coping Strategies for victims of cyberbullying, Journal of Psyhosocial Research on Cyberspace : Cyber Psychology, 2013

Reza. 2015. Pengguna Internet Indonesia Kuasai Media Sosial di 2015, dikutip dari http://tekno.liputan6.com/, diaksespadatanggal05 November 2018

https://www.kominfo.go.id/content/detai 1/8566/mengenal-generasi-

millennial/0/sorotan media, diakses pada tanggal 01 november 2018

UU ITE No.11 Pasal 27 Tahun 2008

(Undang Undang Informasi dan Transaksi Elektronik) 